DOI: 10.1515/linpo-2015-0012

\title{
Indo-Aryan ergativity and its analogues in languages of Central and Western Eurasia
}

\author{
Boris Zakharyin
}

Moscow State University, zakharyin@iaas.msu.ru

\begin{abstract}
Boris Zakharyin. Indo-Aryan ergativity and its analogues in languages of Central and Western Eurasia. The Poznan Society for the Advancement of Arts and Sciences, PL ISSN 0079-4740, pp. 63-75

Ergativity, being a typologically significant feature, serves as basis for a bunch of genetically and structurally different languages of Eurasia. The paper suggests the bird's eye view of its manifestation in the selected samples of Indo-Iranian, Tibeto-Burman, Caucasian and Euskara (the Basque language of Spain). The provided analysis allows to assume that split ergativity displayed by certain Indo-Iranian languages is of the same (participial) origin and partially may have also been influenced by contactfactors. Consistent ergativity characterizing the majority of the Caucasian languages and Euskara is a phenomenon of semo-syntactic nature realizing itself on all the grammatical levels.
\end{abstract}

Keywords: ergativity, Eurasia, Indo-Iranian, Tibeto-Burman, Burushaski, Caucasian, Euskara, semosyntactic

Ergativity in its consistent or split varieties is the syntactic feature which allows to uniformly analyze languages of different genetic formations - the Indo-Iranian, the TibetoBurman, the Caucasian languages and the genetically isolated Euskara (Basque). One of the definitions of the notion 'ergativity' accepted here has been suggested by Dixon. It has been based on the assumption that there exist three universal syntactic primitives: transitive subject $(\mathbf{A})$, transitive object $(\mathbf{O})$, intransitive subject $(\mathbf{S})$, - and two main types of combining the primitives. - When $\mathbf{S}$ and $\mathbf{O}$ imply the same markers and $\mathbf{A}$ is marked differently we deal with an ergative arrangement, but when markers for $\mathbf{S}$ and $\mathbf{A}$ are identical and those for $\mathbf{O}$ differ an accusative arrangement is meant. In both these cases we talk about 'morphological' or 'intra-clausal' ergativity (Dixon 1994: 16). Modifications of this model have been proposed by Klimov (1983: 113) and also by Manning and Stroński - in particular, the latter two have demonstrated that the basis for differentiation lies not in markers but in the sphere of mapping the arguments: the syntactically ergative system maps agent onto object and patient onto subject function while in the syntactically accusative language it is vice versa (Manning 1996: 3; Stroński 2011: 19). Other additions to the concept of ergativity belong to Comrie who has defined it as "passive syntax without the basic active counterpart" (Comrie 
1978: 339). The important result of this approach is clustering of the majority of subject properties in agent - the process by which the language structure becomes more oriented towards the semantic roles than towards the syntactic categories.

The ergative Indo-Aryan languages form two different sets, roughly coinciding with G. Grierson's division of Neo-Indo-Aryan into the "Outer Branch" and the "Inner Branch" (Grierson 1931-3). The first set is formed, among others, by Classical Dakkhini, "Dardic" Shina, ${ }^{1}$ Nepali, Assamese and, probably, by Old Bengali. The other set consists of the rest of the ergative Indo-Aryan languages of Northern and Central India. The two sets demonstrate differences in ways of expressing ergativity: in languages of the first group it is more or less consistent, while the languages of the second group are characterized by split ergativity.

In Assamese and Nepali transitive and intransitive verbs are differentiated only syntactically, but in Shina they are also opposed morphologically, as postfixes in transitive and intransitive forms of Past Indicative or Imperative are different; the same type of morphological contrast characterizes forms of conjunctive participles. Any transitive verb-form in Shina normally implies marking of A/SBJ by the ergative postposition $s / s e$, suspiciously equivalent to functionally identical postposition of Literary Tibetan (see below), or - in certain contexts - the A/SBJ NP may be left unmarked. The verb almost always (the exceptions are implied, e.g., by Future tense forms) agrees with A/SBJ in Person [the opposition 'speaker ( $1^{\text {st }}$ person $) \leftrightarrow$ non-speaker $\left(2^{\text {nd }}+3^{\text {rd }}\right.$ persons]' reminds that one of Tibetan $)$ and in Number (with the opposition ' $\mathrm{SG} \leftrightarrow \mathrm{PL}$ '); in $\mathrm{SG}$ forms the Gender opposition ' $\mathrm{m} \leftrightarrow \mathrm{f}$ ' is also manifested:

$$
\begin{aligned}
& \text { ma } s \quad \text { hare-m-usus } \\
& \text { 1SG.m ERG take-1SG.ERG - 1SG.m } \\
& \text { 'I (m) have taken (it)' } \\
& \begin{array}{l}
m a \quad s \quad \text { hare-m-isis } \\
\text { 1SG.f ERG take-1SG.ERG-1SG.f } \\
\text { 'I (f) have taken (it).' }
\end{array}
\end{aligned}
$$

The situations in Nepali, Assamese (which, probably, reflects the early phase of evolution of the whole group of Magadhian languages, including Old Bengali) and also in Classical Dakkhini are similar to that one described for Shina. In Assamese, Nepali and Classical Dakkhini any transitive form occupying the predicate position demands that the sentence construction should follow the ergative pivot $\mathbf{S} / \mathbf{O} \leftrightarrow \mathbf{A}$, while its intransitive correlate implies the nominative/accusative pivot $\mathbf{S} / \mathbf{A} \leftrightarrow \mathbf{O}$. In transitive sentences the A/SBJ NP is obligatorily marked by the ergative postposition: $e / i$ in Assamese, le in Nepali and le/ne in Classical Dakkhini; ${ }^{2}$ in intransitive constructions it remains unmarked. The verbal agreement in any type of sentences is invariably with the A/ SBJ:

1 There are varied genealogical classifications of the languages of Afghanistan and of the North-West of India. The author's position on the subject is near to that of Fussman (1972) and Strand (1973). Strand, for example, suggests to separate Nuristani (that is 'Kafir' or 'Dardic proper') languages from those belonging to "Dardic" subgroup inside Indo-Aryan. To avoid confusion, the latter subgroup will be marked by the term "Dardic" (with quotation marks) - it includes into itself Shina, Kashmiri and some other languages of Dardic origin spread in Pakistan and Central Afghanistan.

2 In earliest texts the ergative postposition in Classical Dakkhini was $l e$, later changed for $n e$. There is no ergativity in Modern Dakkhini. 
Assamese:

$\begin{array}{llll}\text { ram } e & k a m-\varnothing & k \supset r-i b-\jmath \\ \text { Ram ERG } & \text { work-ABS } & \text { do-FUT-3SG } \\ \text { 'Ram will do the work.' } & \end{array}$

ram- $\varnothing \quad a h-i b-\supset$

Ram-ABS come-FUT-3SG

'Ram will come.'

Nepali:

(5)

$\begin{array}{llll}\text { mai } & \text { le } & \text { kitāp- } \varnothing & \text { paRh-ẽ } \\ \text { I. OBL.Sg ERG } & \text { book-ABS } & \text { read.PST 1SG } \\ \text { 'I read the book.' } & & \end{array}$

$\begin{array}{ll}m a & g a-\tilde{e} \\ \text { I. ABS } & \text { go. PST 1SG } \\ \text { 'I went away.' }\end{array}$

Dakkhini:

$$
\begin{aligned}
& \text { rāṇi-Ø ga-ì h-ai } \\
& \text { queen.f- ABS go. PTCP PFV- f.SG AUX. PRS - } 3 \text { SG } \\
& \text { 'The queen has gone.' } \\
& \begin{array}{lllll}
\text { mai } & \text { le } & \text { saugandh- } \varnothing & k h \bar{a}-y-\bar{a} & h-\varnothing \\
\text { I. ABS } & \text { ERG } & \text { oath.m-ABS } & \text { eat-PTCP PFV-m.SG } & \text { AUX. PRS- 1SG } \\
\text { 'I have given oath.' (= lit. 'I have eaten oath.') } &
\end{array}
\end{aligned}
$$

Languages of the second set imply split ergativity which is organized by the participial component of the predicate characterized by cooccurrence in it of features 'transitivity' and 'perfectiveness'; only under this condition the A/SBJ NP may acquire the ergative case marker. The agreement patterns in different languages of the set are manifold: the verb there may show agreement in Person/Number with A/SBJ or in Gender/Number with P/DO, or it may be fully absent, and in such cases the verb adopts the so called 'fixed form'. Some dialects of Marwari also demonstrate specific cases of split agreement when the participle agrees in Gender/Number with P/DO while the auxiliary verb agrees in Person/Number with A/SBJ (see below).

The languages of this set situated in the West of India show additional complexities concerning functioning of pronouns and nouns in ergative sentences. For example, in the ergative domain of Punjabi personal pronouns in the A/SBJ position are not to be marked by

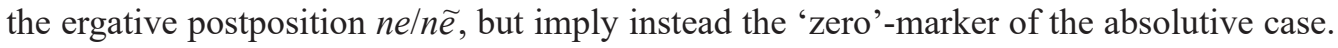
When occupying the P/DO position, the same pronouns, functioning as Identified Object Markers (IOM), must obligatorily be marked by the DAT postposition $n \tilde{\bar{u}}$. - The use of the latter prevents verbal agreement with any NP of the sentence, and the verb then takes its 'fixed form' (normally, that one of $\mathrm{m} / \mathrm{n} \mathrm{SG}$ ). In 'maximally central' Hindi the situation is slightly different: similarly to Punjabi Hindi also uses IOM (represented by DAT postposition $k o$ ) with the $\mathrm{P} / \mathrm{DO}$ pronouns, but, contrary to Punjabi, it allows the ergative postposition ne with any types of nominals. Compare in this respect Hindi (9) and Punjabi (10); both the sentences in these two languages imply the same meaning 'You have seen me': 
(9)

\begin{tabular}{|c|c|c|c|c|c|}
\hline & ne & mujh & ko & $\operatorname{dek} h-\bar{a}$ & $\begin{array}{l}h-a i \\
\text { AUX.PRS-3SG }\end{array}$ \\
\hline You. ABS & ERG & BL SG & DAT & see. PTCP PFV-m. SG & AUX.PRS-3SG \\
\hline tus $\tilde{\bar{l}}$ & mai & & $n \tilde{\bar{u}}$ & vekh-i-ā & $h-a i$ \\
\hline You. ABS & I. $\mathrm{AB}$ & OBL SG & DAT & see-PTCP PFV- m. SG & AUX.PRS- 3 SG \\
\hline
\end{tabular}

The most archaic variety of split ergativity demonstrates "Dardic" Kashmiri where the verb agrees in Gender/Number with P/DO and in Person/Number (through pronominal affixes) with A/SBJ. The order of affixes in a verb-form is fixed: first are used the Gender/ Number affixes which in ergative domain characterize P/DO, in non-ergative - A/SBJ. After them the Person/Number affixes (obligatory for $2 \mathrm{SG}$ ) come in the following hierarchical order: $\mathrm{A}-\mathrm{P}-\mathrm{EXP} / \mathrm{REC} / \mathrm{POSS}$. The latter linear order is non-transformable or non-permutable, and any 'zero' representation of the previous element allows the whole chain of affixes to move one step to the left. E.g.:

$$
\begin{array}{lll}
m \text { 'a } & \multicolumn{1}{c}{\text { chel-i-m }} & \text { pal-av } \\
\text { I.A.m/f. SG.ERG } & \text { wash. PTCP PFV-m PL-A.1SG } & \text { cloth.P -m PL } \\
\text { 'I washed the clothes.' (Koul \& Hook 1984: } & \text { 128) }
\end{array}
$$

Kashmiri lacks the mechanism of IOM spread on any kind of nominals. When both the main syntactic positions are occupied by pronouns, affixes in a verb-form show agreement with P/DO in Gender /Number and with A/SBJ and P/DO in Person / Number; the pronoun in P/DO position has a 'zero'-marker of the absolutive case, that is, remains unmarked:

$$
\begin{array}{lll}
\text { ts 'a } a r-u-t h-a s & \text { ma } \\
\text { you.SG. ERG } & \text { kill.PTCP PFV.m.SG - P.m SG - A.2SG - P.1SG } & \text { I.P.ABS } \\
\text { 'You killed me.' } &
\end{array}
$$

In the ergative domain of the 15th century Marwari an analytic transitive verb-form had agreement with P/DO in Gender/Number and also in Person/Number; IOM, similar to what is taking place in nowadays Kashmiri, was altogether absent in the system:

$\begin{array}{llll}\text { Srīpur nagar nāyak-i } & \text { amhe } & \text { mokal-iy- } \bar{a} & c h-\bar{a} \sim \\ \text { Shripur city ruler.A - INS SG } & \text { we.P.m PL ABS } & \text { send- PTCPPFV-m PL } & \text { AUX.PRS-3PL } \\ \text { 'The ruler of Shripur city has sent us ...' } & \text { (Khokhlova 2001: 173) }\end{array}$

But in the ergative domain of Modern Marwari the transitive verb always (in spite of possible presence of IOM for which the dative postposition nai is used) agrees with P/DO only in Gender/Number and not in Person/Number:

$\begin{array}{llll}\text { Gìta } & \text { Rāwan } & \text { nai } & m \bar{a} r-i y \text {-au } \\ \text { Gita. A.f SG. ABS } & \text { Rawan.P. m SG. ABS/Obl } & \text { DAT } & \text { kill- PTCP PFV -m SG }\end{array}$

'Gita killed Rawan.'

There also exist dialectal varieties of Modern Marwari where in ergative domain the participial component of the predicate agrees with $\mathrm{P} / \mathrm{DO}$ in Gender/Number while auxiliary verb demonstrates Person/Number agreement with A/SBJ:

$$
\begin{aligned}
& \text { mhaĩ saugan- } \varnothing \quad \text { lai } l-\bar{l} \quad h-\tilde{\bar{u}} \\
& \text { I.A.SG. ERG oath. P. f SG- Abs/Obl take.CONJ take.CVB.PST-fSG AUX.PRS-1SG } \\
& \text { 'I have sworn an oath.' }
\end{aligned}
$$

3 The phenomenon was first described by Magier (1983: 250) and later on confirmed by Khokhlova to whom the above given sample belongs (Khokhlova 2001: 168). 
In ergative domain of Braj the verb agrees in Gender/Number with P/DO, but if the latter is represented by 1 st or 2 nd persons pronouns, the verb will additionally agree in Person/ Number:

$$
\begin{aligned}
& \text { tai } \quad n \tilde{e} \ldots \quad m a \tilde{i} \ldots \quad \text { bacā-y-au } \tilde{\bar{u}} \\
& \text { you. A.Obl SG ERG I. P.m SG. ABS save- PTCP PFV-m SG AUX.PRS.1 SG } \\
& \text { 'You have saved me.' }
\end{aligned}
$$

Braj already possesses IOM, but it remains optional: the pronoun functioning as P/DO normally is marked by 'zero'-marker of ABS [as in (16) above], but it may also be followed by by the dative postposition $k \bar{u}(\sim)$ serving as IOM; presence or absence of $k \bar{u}(\sim)$ has no effect on verbal agreement which is oriented on P/DO:

$$
\begin{array}{lllll}
\text { unhõ } & n e \ldots m o & k \bar{u} & k h \bar{u} b & m \bar{a} r-\bar{l} \\
\text { they.A.m PL.OBL } & \text { ERG I.P. f SG. OBL } & \text { DAT } & \text { well.ADV } & \text { beat. PTCP PFV - f SG } \\
\text { 'They (m) ... beat me (f) heavily.' } & & &
\end{array}
$$

The split ergativity also exists in a number of Iranian languages: in Pashto, Tati, Kurmanji, Yaghnobi, etc.; the signs of its previous existence are evident even in now accusative Persian. On the superficial level the mechanism of ergativity in Iranian seems to differ considerably from that one in Indo-Aryan, as in Iranian it is determined by past tense of transitives. This state of things is well illustrated by Pashto: any past tense form of a transitive verb in the language determines marking of $\mathrm{A} / \mathrm{SBJ}$ by the ergative case which coincides with the oblique. The P/DO NP is in the unmarked absolutive case, and the verb agrees with it in Gender/Number/Person; similar to Kashmiri, no IOM exists even with personal pronouns having property of $\mathrm{P} / \mathrm{DO}$ :

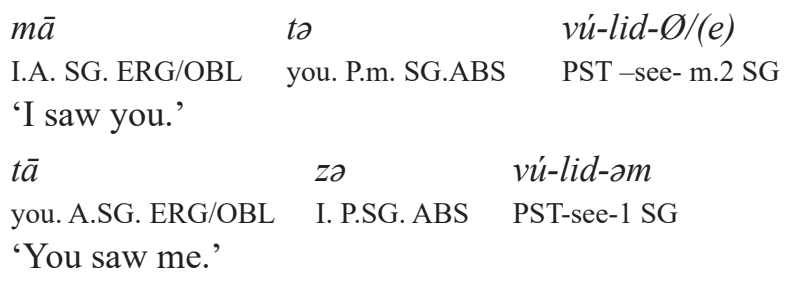

But from the diachronic point of view ergativity in Iranian and Indo-Aryan is of the same origin: its sources are constructions with Proto-Indo-European verbal adjectives in *-to/-no, which later on have become participles with perfective/resultative meaning. In Iranian their further development has gone along the temporal axe, while in Indo-Aryan aspect has become their dominant feature. Both - the Indo-Aryan and Iranian - language-groups exhibit ergativity in respect to case-marking and verb-agreement, and members of both the groups demonstrate deviations from either case- marking rules, or from agreement pattern, or even from both of these devices. The contact factor may also have been significant as, on the one hand, Eastern Iranian and Western Indo-Aryan (including "Dardic" Shina and Kashmiri), having split ergativity, suspiciously demonstrate geographical closeness towards each other and, on the other, Assamese, Nepali and, probably, also Old Bengali as systems with more or less consistent ergativity may for a long time have been in tight contacts with the consistently ergative Tibeto-Burman languages.

4 The Braj samples are from Liperovsky 2011: 145-152. 
A number of the Tibeto-Burman languages, including Literary Tibetan, possess ergativity of nominal type: a transitive verb occupying the predicate position determines marking of the A/SBJ NP by a certain ergative marker. The P/DO of transitives and A/SBJ of intransitives are left unmarked; the verb-agreement is altogether absent. Typical are, e.g., situations in Tibetan and Ladakhi - the former uses postposition $(g i) s / s(\mathrm{e})$, the latter - affix $-e /-\dot{n} i$ for marking the ergative case of the A/SBJ NP:

Tibetan:

$$
\begin{array}{ll}
\text { khong } & \text { 'gro } \\
\text { 3SG.ABS } & \text { go. PRS }
\end{array}
$$

'He goes.'

$\begin{array}{llll}\text { khong } & \text { gis } \quad \text { rtag } & \text { bsad } \\ \text { 3SG } & \text { ERG. tiger. ABS } & \text { kill.PST } \\ \text { 'He killed the tiger.' } & \end{array}$

Ladakhi:

kho son-pin
he.ABS enter-PSTPRF
'He had entered.'
kho-e spećho khyers
he-ERG book.ABS take.PRF
'He has taken a book.'

$\begin{array}{lll}\dot{n}-e \quad k h o-\partial \quad \text { spećho } & \text { təri-ñt } \\ \text { I-ERG he-DAT book.ABS } & \text { give-PRS } \\ \text { 'I give him a book.' } & \end{array}$

$\begin{array}{lll}\dot{n}-e & \text { kho } & \text { sats-pin } \\ \text { I-ERG he.ABS } & \text { kill- PSTPRF } \\ \text { 'I had killed him.' }\end{array}$

The ergative languages of Caucasus may be distributed into several groups. Group (1) is formed by Nach-Daghestan languages with their maximally consistent semo-syntactic ergativity; group (2) consists of Abkhaz-Adygh languages which do not have any means of case-marking in nominals, but concentrate their consistent ergativity in the system of verb; group (3) is represented by languages like Lezgin and Agul with exclusively nominal (latest) type of ergativity; group (4) is constituted by Kartvelian languages (like Georgian, Swanish, etc.) characterized by split ergativity.

In the Darghin language of Daghestan the semantic roles are in direct correlation with the corresponding morphological markers: in a transitive sentence the A/SBJ NP is marked by affix of the ergative/instrumental case and the P/DO NP - by 'zero' marker of the absolutive case which also marks the A/SBJ NP of an intransitive sentence. In a transitive verbform prefixes express the Class/Number properties of the Patient, and postfixes mark the Person/Number characteristics of the Agent:

5 The samples of Ladakhi sentences have been borrowed from Koshal 1979: 65-109. 


$\begin{array}{ll}n u-n i \quad \text { uta } & \text { b-jak'il-la } \\ \text { I.SG - ERG/INS chair. SG. ABS } & \text { NHUM.SG - make. PST - 1SG } \\ \text { 'I made a chair.' } & \end{array}$

$$
\begin{aligned}
& \text { nu- } \varnothing \quad \text { w-ak'i-ra } \\
& \text { I. SG - ABS m. SG -go.PST - 1Sg } \\
& \text { 'I went away.' }
\end{aligned}
$$

The ergativity system of Tsakhur is similar to that one of Darghin, but Class markers in Tsakhur verb-forms may also be infixes, not only prefixes as in Darghin. Besides, functioning of the 1 st and 2 nd person pronouns of Tsakhur in $\mathrm{A} / \mathrm{SBJ}$ position implies neutralization of opposition between the ergative and absolutive cases - the phenomenon analogues with that one of Punjabi:

$$
\begin{aligned}
& \text { istol- } \quad \text { ali-w-šu-na } z-\dot{t} \\
& \text { table. m.NHUM. SG - ABS buy. - m.HUM.SG - PRF - ADJ I. m.SG - ABS/ERG } \\
& \text { 'I (m) have bought the table.' } \\
& z-\dot{i} \quad a-r-\dot{t} \\
& \text { I. } \mathrm{m} . \mathrm{SG}-\mathrm{ABS} / \mathrm{ERG} \quad \text { come.m.SG - PRF } \\
& \text { 'I (m) have come.' }
\end{aligned}
$$

\begin{tabular}{|c|c|}
\hline brigadirz-r & $m a-k I o$ \\
\hline brigade-leader. SG - ABS & A. $3 \mathrm{SG}-$ go.PRS \\
\hline
\end{tabular}

Languages of group (2) demonstrate some differences: while nominals in Adygh are characterized by the morphological opposition 'ergative/oblique - absolutive', their Abkhazian counterparts do not imply cases-marking system at all; the Class/Person distinctions of $\mathrm{A} / \mathrm{SBJ}$ and of $\mathrm{P} / \mathrm{DO}$ are directly reflected in agreement patterns of verb-forms. In Adygh $-m e(e)$ is used as ergative marker for $\mathrm{A} / \mathrm{SBJ}$ of transitives, and $-r$ as absolutive marker for $\mathrm{A} /$ SBJ of intransitives and for P/DO of transitives: ${ }^{6}$

Ergativity in Adygh is not constrained with the opposition of ergative - absolutive cases, it is also entangled with additional grammatical contrasts - such as, e.g., 'definiteness - indefiniteness' in nominals and 'concrete - non-concrete (action)' in verbs. (The latter opposition is similar to that one which is significant for ergative domain in Nepali). In forms of transitives it is expressed by transfixes $e-\ldots-\partial$ ('concrete') $\leftrightarrow m a-/ m e-\ldots-e$ ('non-concrete'): $e$-lažI-ə '(he) is working (with some definite object)' $\leftrightarrow$ me-lažI-e '(he) is at work' (= 'his occupation is work in general'). If in a sentence with a non-concrete transitive verb P/DO is represented by 'definite' NP, the ergative $-m$ of A/SBJ is to be replaced by the absolutive marker $-r$. In case the 'indefinite' status of the P/DO NP is to be expressed, the absolutive $-r$ is replaced by 'zero'; other components of a verb-form remain intact. - Compare pairs (33) $\leftrightarrow(34)$, on one hand, and (35) $\leftrightarrow(36)$, on the other:

6 It is not clear whether $-r$ and $-m$ are postfixes or, probably, postpositions, thus, the status of these markers is debatable. The Adygh samples are from Meschaninov 1967: 62-64. 


$$
\begin{aligned}
& \text { uchitela-he-r śkola-m ma-kIo-h(a) } \\
& \text { teacher-PL-Abs school-Obl 3SG-go-PL.Intr } \\
& \text { 'The teachers go to school.' }
\end{aligned}
$$

$\begin{array}{lll}\text { šauzว-m } & \text { jane- } r & e-d-\partial \\ \text { woman.SG - ERG } & \text { shirt.SG - DEF } & \text { CONCR -sew- CONCR }\end{array}$

'The woman is sewing (this very) shirt.'

$\begin{array}{ll}\text { šauza-r } & m a-d-e \\ \text { woman.SG -ABS } & \text { NCONCR-sew- NCONCR }\end{array}$

'The woman is busy with sewing.' (= 'Sewing is this woman's occupation.')

$$
\begin{aligned}
& \text { cetyu-m tsigao-r e-ubat-ə } \\
& \text { cat. SG -ERG mouse. SG - DEF CONCR - catch - CONCR }
\end{aligned}
$$

'The cat is catching the (concrete) mouse.'

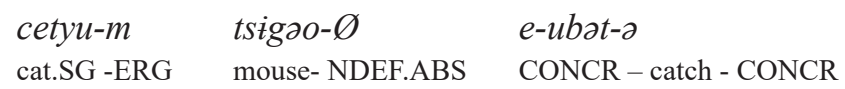

'The cat (normally) catches a mouse.' (= 'To catch a mouse is in a habit of any cat.')

If in intransitive sentence the non-concrete status of A/SBJ is to be expressed, the 'zero' marker of the absolutive case is used instead of $-r$ :

$$
\begin{aligned}
& \check{s} \text { ว-r hatem- } \varnothing \quad \text { dehIa-ga } \\
& \text { horse.SG - CONCR kitchen-garden-ABS penetrate.-PST } \\
& \text { 'The (concrete) horse penetrated the kitchen-garden.' } \\
& \text { ša-Ø hatem- } \varnothing \quad \text { dehIa-ga } \\
& \text { horse.SG - NCONCR kitchen-garden - ABS penetrate.-PST } \\
& \text { 'Some (unknown) horse penetrated the kitchen-garden.' }
\end{aligned}
$$

In Abkhazian, the other member of group (2), nominals are not declined, but personal pronouns imply oppositions in Person, other pronouns and nouns are characterized by Class - distinctions; all these features are mirrored in verb-forms. The verbal stems imply differences in transitivity only semantically and do not express them morphologically, but the conjugated verb-forms express the opposition through sets of prefixes. - Class-characteristics of any nominal in $\mathrm{SG}$, functioning as $\mathrm{A} / \mathrm{SBJ}$ of a transitive sentence, are reflected by verbal prefixes: $i$ - for 'masc. human', $l(\partial)$ - for 'fem. human', $a$ - for 'non-human'; with nominals in PL the opposition is only 'human (prefix $d / d \partial-$ ) - non-human (prefix $i-$ )'. The other set of verbal prefixes marks the properties of intransitive A/SBJ and of transitive $\mathrm{P} /$ $\mathrm{DO}$; still other set of verbal prefixes serves for expressing differences of pronouns in Person. As cases are absent, the order of NPs in a sentence is normally fixed and correlates with the syntactic functions of NPs: first comes the A/SBJ NP, after it follows the NP representing Experiencer/Recipient/Possessor, the 3rd position is occupied by the P/DO NP. Inside the verb-forms the order of prefixes is different - the 1st position is occupied by prefixes expressing $\mathrm{P} / \mathrm{DO}$, the $3 \mathrm{rd}$ - by prefixes of $\mathrm{A} / \mathrm{SBJ}$; prefixes expressing other roles are placed between those two:

$$
\begin{array}{lll}
s-a b & a t \text { 'š } & i-i-g-o y t \\
\text { my-father } & \text { stallion } & \text { NHUM -HUM. m - take - PRS } \\
\text { 'My father a stallion takes.' } \quad \text { (= lit. 'it-he-takes') }
\end{array}
$$


(40)

$$
\begin{array}{lll}
\text { so-p'ha } & \text { at'š } & i-l-g-o y t \\
\text { my-daugher } & \text { stallion } & \text { NHUM-HUM.f - take - PRS }
\end{array}
$$

'My daughter a stallion takes.' (= lit. 'it-she-takes')

$$
\begin{array}{llll}
\text { ag'at'sa } & \text { sə-p'ha } & \text { at'š } & i \text {-l-i-g-oyt } \\
\text { man.SG/PL } & \text { my-daughter } & \text { stallion } & \text { NHUM-HUM.f-HUM.m-take - PRS }
\end{array}
$$

'Man a stallion for my daughter takes.' (= lit. 'it-her for - he -takes')

Compare transitive structures with the intransitive one:

$$
\begin{array}{ll}
s \partial-p \text { 'ha } & \text { lo-t's-oyt } \\
\text { my-daugher. } & \text { HUM.f - go - PRS } \\
\text { 'My daughter goes.' (= lit. 'she-goes') }
\end{array}
$$

The nominal components of a sentence may be omitted as the verb with its prefixes expresses the necessary meaning:

$$
\begin{aligned}
& i \text {-sa-l-t-eyt } \\
& \text { NHUM - REC.1SG - A.HUM.f - give - PST } \\
& \text { 'She it to me gave.' (= lit. 'it - me to - she - gave') }{ }^{7}
\end{aligned}
$$

The phenomenon reminds Kashmiri verbal structures of the type wuchu-th-as 'I saw you' (lit. 'seen - by you - I'), but contrary to Abhazian, Kashmiri uses postfixes, not prefixes.

In Lezgin, as a member of group (3), verbs are devoid of any categories expressing agreement with NPs; the system of case-marking is typical for ergative languages: postfix -di marks A/SBJ in a transitive sentence, the 'zero'- affix of the absolutive case marks A/SBJ of intransitives and $\mathrm{P} / \mathrm{DO}$ of transitives:

$$
\begin{aligned}
& z-i \quad \text { balkIan galat-na } \\
& \text { I- SG. GEN horse. SG. ABS get tired-PST } \\
& \text { 'My horse got tired.' } \\
& \text { balkIan-di } \quad z-i \quad n i k-\varnothing \quad \text { barbatI-na } \\
& \text { horse.- ERG I- SG.GEN field-SG.ABS spoil.-PST } \\
& \text { 'The horse spoiled my field.'8 (Meschaninov 1967: 68-73). }
\end{aligned}
$$

The same type of ergativity is present in Agul which slightly differs from Lezgin as its personal pronouns, irrespective of transitivity/intransitivity of the verb, imply 'zero'-marker of the absolutive case - the situation is thus similar to one existing in Punjabi (see above).

The majority of Kartvelian languages, forming group (4), are characterized by split ergativity determined by temporal features of the verb (Iranian type): the Aorist tense of transitives implies ergative marking of $\mathrm{A} / \mathrm{SBJ}$; in the Perfect tense it is marked by dative; in the Present tense of a transitive verb and in any tense of an intransitive A/SBJ is to be marked by absolutive. The situation in Kartvelian is well illustrated by Georgian where in case of Aorist tense-forms of transitives A/SBJ is marked by ergative - $m a$ and $\mathrm{P} / \mathrm{DO}$ - by absolutive $-i$; in Perfect tense-forms the dative $-s(a)$ is used for A/SBJ and P/DO is marked by the absolutive $-i$; in the Present tense the absolutive $-i$ is used for A/SBJ, the dative $-s$ for P/DO. Class-differentiation is irrelevant for Modern Georgian, and the verbal agreement

7 The Abhazian samples are from Meschaninov 1967: 65-66, 87-88.

8 The Lezgin samples belong to Meschaninov 1967: 68-73. 
(in categories of Person/Number) is normally with $\mathrm{A} / \mathrm{SBJ}$, but it may also be with P/DO if the latter is represented by a pronoun:

$$
\begin{array}{lll}
\text { kat's-ma } & \text { sahl-i } i \text { ašen- } a \\
\text { man - ERG } & \text { house -ABS } & \text { build-AOR } \\
\text { 'The man built the house.' }
\end{array}
$$

$\begin{array}{lll}\text { kat's- } i & \text { sahl-s } & \text { ašen-eb-s } \\ \text { man-ABS } & \text { house -DAT } & \text { build -PRS - 3 SG }\end{array}$

'The man is building the house.'

$$
\begin{array}{lll}
\text { qal-sa } & \text { est-o } & d z a p \text { '- } i \\
\text { woman-DAT } & \text { spin -PRF } & \text { thread-ABS }
\end{array}
$$

'The woman has (evidently) spun the thread.'

The Euskara (Basque) language, spread in circum-Pyrenesian area, is represented by a great number of dialects, even the literary standard implies four different varieties. Euskara happens to be a descendant of the language of settlers of Ancient Iberia that inhabited the country long before the arrival there of Roman and Germanic tribes, genetically it does not belong to any of known groups. Morpho-syntactically Euskara is consistently ergative: $\mathrm{A} / \mathrm{SBJ}$ of transitives is marked by the ergative case affix $-k$, while $\mathrm{P} / \mathrm{DO}$ of transitives and $\mathrm{A} /$ SBJ of intransitives imply 'zero'- markers of the absolutive case. The grammatical features of $\mathrm{A} / \mathrm{SBJ}$ and $\mathrm{P} / \mathrm{DO}$ are also mirrored by affixes in verb-forms. In present tense forms of intransitives affixes almost fully coincide with the corresponding personal pronouns occupying the A/SBS position. But in present tense forms of transitives postfixes marking A/SBJ and prefixes marking $\mathrm{P} / \mathrm{DO}$ considerably differ from prototypical pronouns:

$$
\begin{aligned}
& \text { ni-Ø na-bil } \\
& \text { I. } \mathrm{SG}-\mathrm{A} \text {. ABS A. } 1 \mathrm{SG} \text { - go.PRS } \\
& \text { 'I go.' } \\
& n i-k \quad d \text {-aki-t } \\
& \text { I.SG - A. ERG PRS.3SG - know- A. I. SG } \\
& \text { 'I know it.' (lit. 'it-know-I') }
\end{aligned}
$$

The Euskara sentences, organized by transitives in the past tense and having pronominal $\mathrm{A} / \mathrm{SBJ}$ s and P/DOs of the 3rd Person, may completely omit the nominal components, but specificity of the remaining verb-forms lies in the fact that $\mathrm{A} / \mathrm{SBJ}$ is to be expressed not by ordinary postfixes, but by prefixes, formally similar to those used in the present tense for $\mathrm{P} /$ DOs of transitives or for A/SBJs of intransitives. Compare in this respect the pair of sentences, organized by the verb erama-/arama- 'to carry' and implying either present (51) or past (52) tenses:

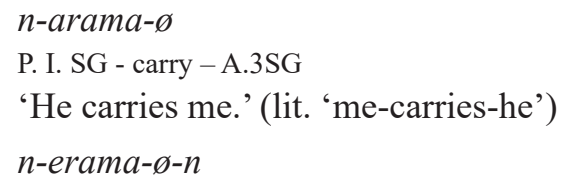


The number of stems generating synthetically composed verb-forms in Euskara is very small, normally only the analytic tense/mood expressions are in use. The first component in them is a certain indeclinable participle and the second element is represented by forms of two auxiliaries - either by izan 'to be' (used with intransitives) or by ukan 'to have' (used with transitives). The first component of the analytic expression (normally implying an aspect-marking postfix) serves to express the lexical meaning, while the grammatical markers are concentrated in the auxiliary. There are (rare) cases when a semantically intransitive verb determines marker of the ergative case $-k$ for $\mathrm{A} / \mathrm{SBJ}$ and simultaneous use of the transitive auxiliary ukan-:

$$
\begin{array}{lll}
u r-a-k & \text { iraki-n } & d-u \\
\text { water-DET-ERG } & \text { boil - PRF } & \text { AUX.TR .A. 3SG - PRS } \\
\text { 'The water has boiled.' } &
\end{array}
$$

The opposite process, when in a transitive sentence the ergatively marked A/SBJ is elided and only the 'zero'- marked P/DO remains, may also take place; auxiliary in such cases is represented by forms of intransitive izan- 'to be' (and not of ukan- 'to have'):

$\begin{array}{llll}\text { norbaite- } k & \text { etxe- } a-\varnothing & s a l-d u & d-u \\ \text { A. someone- ERG } & \text { P. house-DET - ABS } & \text { sell-PRF } & \text { AUX.TR. PRS - A. 3SG }\end{array}$

'Someone has sold the house.'

$$
\begin{array}{lcl}
\text { etxe- } a-\varnothing & \text { sal-du} & d-a \\
\text { P.house- DET - ABS } & \text { sell - PRF } & \text { AUX.INTR. PRS - P.3SG } \\
\text { 'The house has been sold.' } &
\end{array}
$$

Pairs of sentences like (54) and (55) seem to allow us to suppose that Passive transformation is at work here. But the assumption is unwarrantable: as Bossong has shown, the Euskara verbal system does not possess the grammatically expressed diatheses, because the language has no functional motivation for either promotion or demotion of any of the corresponding NPs; thus, neither Passive nor Antipassive do exist in Euskara (Bossong 1984 (47): 39).

Almost any Euskara sentence may be transformed into an attributive construction through the help of relativizer $-(a) n /-(e) n$. In this process of relativization the pronominal A/SBJ differing in Person from P/DO may be deleted, still no ambiguity normally arises. Compare in this respect sample (56) and its relativized derivative (56a):

$$
\begin{array}{lcl}
\text { gizona- } & i k u s-i & d u-t \\
\text { man.SG - ABS } & \text { see - PRF } & \text { AUX.TR. PRS - A. 1SG } \\
\text { '(I) have seen the man.' } &
\end{array}
$$

$\begin{array}{lll}i k u s-i & d u \text { - } d \text {-an } & \text { gizona- } \varnothing \\ \text { see-PRF } & \text { AUX.Tr.PRS -A. 1SG - REL } & \text { man. SG-ABS }\end{array}$

'The man whom (I) have seen.'

But when potentially eliminable arguments refer to the 3rd Person, there may appear problems with ambiguity. E.g., for sample (57) of Bossong three different treatments are possible, determined by variegated morphological parceling of the component dio- $n$ (the relativized form of auxiliary, $-n$ being the relativizer): (a) dio- is possibly $d$-ioø- (with prefix $d$ - of the deleted P/DO NP in the absolutive case); (b) it may also be dio- $\varnothing$ - (with - - - mirror- 
ing the A/SDJ NP marked by the ergative case); (c) dio- may also be interpreted as $d i$ - $O$ - $\varnothing$ (where - $O$ - represents the Recipient, originally marked by dative):
ekarr-i dio- $n$ bring - PRF
AUX.TR.3SG / ?ABS/? ERG/? DAT - REL
(a) 'The man whom he' has brought to him',
(b) 'The man who has brought him' to him²',
(c) 'The man to whom he ${ }^{1}$ has brought him²',

gizona- $\varnothing$

man.SG - ABS

Having analyzed other instances of coreferential deletion, Bossong has come to the conclusion that, except some morphologically determined cases (as above), there are practically no restrictions on Euskara NPs' accessibility to relativization or deletion: any NP, belonging to intransitive or transitive sentence and having markers of absolutive, ergative or dative, is deletable or relativizable. According to Bossong, this means that in Euskara syntax neither pivot $\mathbf{A} / \mathbf{S} \leftrightarrow \mathbf{O}$, nor its antagonist pivot $\mathbf{A} \leftrightarrow \mathbf{S} / \mathbf{O}$ are really acting and that Dixon's notions $\mathbf{A}, \mathbf{S}, \mathbf{O}$ and their configurations are in general not applicable to the language (Bossong 1984 (47): 17).

The same typological irrelevancy of primitives $\mathbf{A}, \mathbf{S}, \mathbf{O}$ may also be stated for numerous semantically ergative languages of Daghestan which have been thoroughly analyzed by Kibrik. - As Kibrik remarks, "the difference between ergative and accusative languages lies not in the specificity of expressing 'subject - object relations', but in the fact that, while accusative languages do rely upon those relations as constituents of their structures, the ergative languages do not possess them at all" (Kibrik 1992: 205-206). The structures of Euskara and of Nakh-Daghestan languages are also similar in that (a) they are devoid of such grammatical category as 'voice', (b) the basic word order in them is SOV, that is, the most typical one for consistently ergative languages. In Euskara almost all possible permutations of the sentence constituents are permitted. A few exceptions concern auxiliaries which cannot occupy the initial position; besides, no interpolations between the main verb and the auxiliary following it are possible (Itziar Laka 1996: 1.1.0, 1.1.1).

Taking into account selective coding and behavioral properties - such as case marking, verb agreement, basic word order, relativization rules and absence of the category of voice, - we may come to the following conclusions: inside the analyzed ergative systems the demarcation line disjoints the languages of Western Eurasia from their Central Eurasian counterparts. In languages of Western Eurasia (represented by Euskara and by the NakhDaghestan branch of Caucasian languages) ergativity is a deep-structure phenomenon of semo-syntactic nature. The analyzed samples representing Central Eurasia may be distributed into three main groups: (a) the Tibeto-Burman languages (like, e.g., Ladakhi and Literary Tibetan); (b) the Indo-Aryan/“Dardic" languages of the North and East (like Nepali, Shina, Assamese, etc.); (c) the remaining ergative systems of Indo-Iranian. Languages of group (a) are demonstrating the latest, nominal, phase of consistent ergativity. Very similar to it is the type of ergativity, characterizing members of group (b) - it implies existence of the ergative case marker in nominals and of agreement rules in verbs. The secondary ergativity in these languages has been influenced by long time contacts with Tibetan neighbors. Languages of group (c) possess partial ergativity based on systemic split that has been determined by functional changes in verbal adjectives of Common Indo-European. 


\section{References}

Anderson, Stephen R. 1976. On the notion of subject in ergative languages. In Li, Charles N. (ed.), Subject and Topic, 1-23. New York.

Bossong, Georg. 1984. Ergativity in Basque. Linguistics 23. 341-392.

Comrie, Bernard. 1978. Ergativity. In Lehmann, Winfred P. (ed.), Syntactic Typology, 329-395. Austin: University of Texas Press.

Dixon, Robert M.W. 1994. Ergativity, Cambridge: Cambridge University Press.

Fussman, Gerard. 1972. Atlas linguistique des parlers dardes et kafirs. 2 vols. Paris: École Française d'Extrême Orient.

Itziar Laka 1996 = Brief grammar of Euskara. The Basque Language, 'Brief_grammar_euskara' (pdf).

Khokhlova, Ludmila V. 2001. Ergativity attrition in the history of Western New Indo-Aryan languages. In The Yearbook of South Asian Languages and Linguistics 2001. Papers from the International Symposium on South Asian Languages: Contact, Convergence and Typology, 159-184. New Delhi: Sage Publications.

Kibrik, A.E. 1992. Ocherki po obschim i prikladnym voprosam jazykoznanija (Essays on the general and applied problems of linguistics). Moscow: Moscow State University.

Klimov, G.A. 1983. Printsipy kontensivnoj tipologii (Principles of the contensive typology). Moscow: Nauka.

Koshal, Sanyukta. 1979. Ladakhi Grammar. Delhi-Varanasi-Patna: Motilal Banarsidass.

Koul, Omkar N. \& Hook, P.E. (eds.). 1984. Aspects of Kashmiri Linguistics. New Delhi: Bahri Publications.

Liperovsky, Vladimir P. 2007. Notes on the marking of actants in Braj (in comparison with Modern Standard Hindi). In Masica, Colin P. (ed.), Old and New Perspectives on South Asian Languages. Grammar and Semantics, 144-152. Delhi: Motilal Banarsidass Publishers.

Liperovsky, Vladimir P. 2011. Ocherk grammatiki sovremennogo braja (Grammatical Sketch of Modern Braj). Moscow: Nauka.

Manning, Christopher D. 1996. Ergativity, Argument Structure and Grammatical Relations. Stanford: CSLI Publications.

Meschaninov, Ivan I. 1967. Ergativnaya konstruktsiya v yazykakh razlichnykh tipov (Ergative Construction in Different Types Languages). Leningrad: Nauka.

Montaut, Annie. 2004. A Grammar of Hindi. Lincom-Europa: Lincom GmbH.

Strand, R.F. 1973. Notes on the Nūristāni and Dardic languages. Journal of the American Oriental Society 93(3).

Stroński, Krzysztof. 2011. Synchronic and Diachronic Aspects of Ergativity in Indo-Aryan. Poznań: Wydawnictwo Naukowe UAM.

Zakharyin, Boris A. 1987. Tipologija jazykov Juzhnoj Azii (The Typology of the Languages of South Asia). Moscow: Moscow State University. 
